\title{
Novel EGR2 variant that associates with Charcot-Marie-Tooth disease when combined with lipopolysaccharide-induced TNF- $\alpha$ factor T49M polymorphism
}

Maria Empar Blanco-Cantó, MD,* Nikiben Patel, MSc, * Sergio Velasco-Aviles, MSc, Angeles Casillas-Bajo, BSc, Juan Salas-Felipe, MD, Alexandre García-Escrivá, MD, Carmen Díaz-Marín, MD, PhD, and

Hugo Cabedo, MD, PhD

Neurol Genet 2020;6:e407. doi:10.1212/NXG.0000000000000407

\section{Abstract}

\section{Objective}

To identify novel genetic mechanisms causing Charcot-Marie-Tooth (CMT) disease.

\section{Methods}

We performed a next-generation sequencing study of 34 genes associated with CMT in a patient with peripheral neuropathy.

\section{Results}

We found a non-previously described mutation in EGR2 (p.P397H). P397H mutation is located within the loop that connects zinc fingers 2 and 3, a pivotal domain for the activity of this transcription factor. Using promoter activity luciferase assays, we found that this mutation promotes decreased transcriptional activity of EGR2. In this patient, we also found a previously described nonpathogenic polymorphism in lipopolysaccharide-induced TNF- $\alpha$ factor (LITAF) (p.T49M). We show that the p.T49M mutation decreases the steady-state levels of the LITAF protein in Schwann cells. Loss of function of LITAF has been shown to produce deregulation in the NRG1-erbB signaling, a pivotal pathway for EGR2 expression by Schwann cells. Surprisingly, our segregation study demonstrates that p.P397H mutation in EGR2 is not sufficient to produce CMT disease. Most notably, only those patients expressing simultaneously the LITAF T49M polymorphism develop peripheral neuropathy.

\section{Conclusions}

Our data support that the LITAF loss-of-function interferes with the expression of the transcriptional-deficient EGR2 P397H mutant hampering Schwann cell differentiation and suggest that in vivo both genes act in tandem to allow the proper development of myelin.

\author{
Correspondence \\ Dr. Cabedo \\ hugo.cabedo@umh.es \\ or Dr. Díaz-Marín \\ carmina.diaz.marin@gmail.com
}

*These authors contributed equally to this work.

From the ISABIAL (FISABIO) (M.E.B.-C., N.P., S.V.-A., A.C.-B., C.D.-M., H.C.), Hospital General Universitario de Alicante; Instituto de Neurociencias de Alicante UMH-CSIC (N.P., S.V.-A., A.C.-B., H.C.), San Juan de Alicante, Spain; Hospital Marina Salud (J.S.-F.), Denia; and Hospital IMED Levante (A.G.-E.), Benidorm, Spain. 


\section{Glosary}

ChIP $=$ chromatin immunoprecipitation; CMT $=$ Charcot-Marie-Tooth; CMTNS $=$ CMT neuropathy score; LITAF $=$ lipopolysaccharide-induced TNF- $\alpha$ factor.

Many genes responsible for Charcot-Marie-Tooth (CMT) disease have been identified to date, and it has been estimated that at least other 30 CMT-causing genes could be still discovered in the near future. ${ }^{1-3}$ EGR2 (also known as KROX20) is a transcription factor that activates the myelination program in Schwann cells. ${ }^{4,5}$ Different alterations in the zinc finger region of this transcription factor lead to demyelination causing the autosomal dominant CMT1 type D. ${ }^{6}$ The lipopolysaccharide-induced TNF- $\alpha$ factor (LITAF) is an $18-\mathrm{kDa}$ protein involved in endosomal recycling and protein degradation. Eight missense mutations in the LITAF gene have been associated with autosomal dominant CMT1 type C. $^{7}$ Although some of these mutations cause mislocation of LITAF from the lysosomal membrane to the cytosol and others induce the formation of aggresomes, ${ }^{8,9}$ the exact pathogenic mechanism inducing demyelination remains unknown. Here, we describe a family with a novel mutation in EGR2 (EGR2 P397H). Although the mutation reduces the capacity of this transcription factor to induce myelin gene expression in vitro, in human heterozygotes, this apparently produces no changes in myelin development and nerve function. Of interest, those members of the family who also harbor a nonpathogenic very-low-frequency polymorphism $(<0.001)$ in LITAF $\left(\right.$ LITAF T49M) ${ }^{10}$ developed a full-blown clinical pattern of inherited demyelinating peripheral polyneuropathy. Our data suggest that in these patients, a mild reduction in the function of the LITAF T49M protein can interfere with intracellular signaling and decrease the expression of an already transcriptionally deficient EGR2 P397H, hampering myelin development and nerve function.

\section{Methods}

\section{Family selection}

We selected a white family from the southwest region of Spain without consanguinity (figure 1). In this family, the proband patient and her father had an intermediate hereditary motor and sensory neuropathy.

\section{Next-generation sequencing and analyses}

We extracted DNA from blood and then performed nextgeneration sequencing of a panel of 34 genes correlated with Charcot-Marie-Tooth disease (table e-1, links.lww.com/NXG/ A244). The regions under study were selected by hybridization including exons and adjacent intron regions $(-8,+8)$ of the panel genes. Clonal amplification and sequencing was performed using a paired-end strategy on the Illumina MiSeq platform. Sanger sequencing was accomplished for relevant detected changes and in silico predictive analyses for missense mutations through the Alamut program. We screened variants' frequencies at the Inherited Neuropathy Variant Browser (hihg. med.miami.edu/code/http/cmt/public_html/index.html\#/).

\section{Plasmids}

pGFP-hLITAF and pEGFP-hLITAF T49M were provided by Dr. Philip Woodman and Dr. Lydia Wunderley (University of Manchester, UK). Where necessary, the DNA encoding for green flourescent protein (GFP) was removed with restriction enzymes using standard molecular biology cloning methods to generate phLITAF and phLITAF T49M. A PMP22 intronic enhancer cloned in pGL4 (phPMP22enh-Luciferase) and pcDNA3.1 hEGR2 construct were provided by Dr. John Svaren (University of Wisconsin). pcDNA3.1-EGR2 P397H was generated with the Quikchange Site-Directed Mutagenesis Kit (Stratagene, La Jolla, CA). The correct sequences of the construct were confirmed by sequencing.

\section{Cell cultures}

Schwann cells were cultured from sciatic nerves of neonatal rats as described previously ${ }^{11}$ with minor modifications (see Methods, e-Methods, links.lww.com/NXG/A245). RT4D6P2T rat Schwannoma cells were obtained from Professor Dies Meijer (University of Edinburgh, UK). HEK293 cells were obtained from Sigma-Aldrich (St. Loius, MO).

\section{Reporter activity assays}

Schwann cells or HEK293 cells were transfected with the indicated constructs and then lyzed. Their luciferase activity was determined with the Luciferase Assay System (Promega, Madison, WI) using the manufacturer's recommendations. The $\beta$-galactosidase activity (Beta-Glo Assay System; Promega) of a pRSV40LacZ reporter cotransfected at 1:100 was used to normalize variations in cell number, viability, and transfection efficiency.

\section{Immunofluorescence}

Immunofluorescence studies were performed on cells cultured in coverslips using standard procedures (see Methods, e-Methods, links.lww.com/NXG/A245).

\section{Chromatin immunoprecipitation assays}

The chromatin immunoprecipitation (ChIP) assay followed a modified procedure of the method ${ }^{12}$ (see Methods, e-Methods, links.lww.com/NXG/A245).

\section{DNA-protein binding assay}

The binding of EGR2 to DNA was performed using the DNAProtein Binding Assay Kit from Abcam (ab117139) (see Methods, e-Methods, links.lww.com/NXG/A245).

\section{Standard protocol approvals, registrations, and patient consents}

Human DNA was obtained using protocols approved by our institutional review board. The research was performed in accordance with the Declaration of Helsinki. The Ethical 
Figure 1 Segregation of EGR2 P397H and LITAF T49M mutations in the family
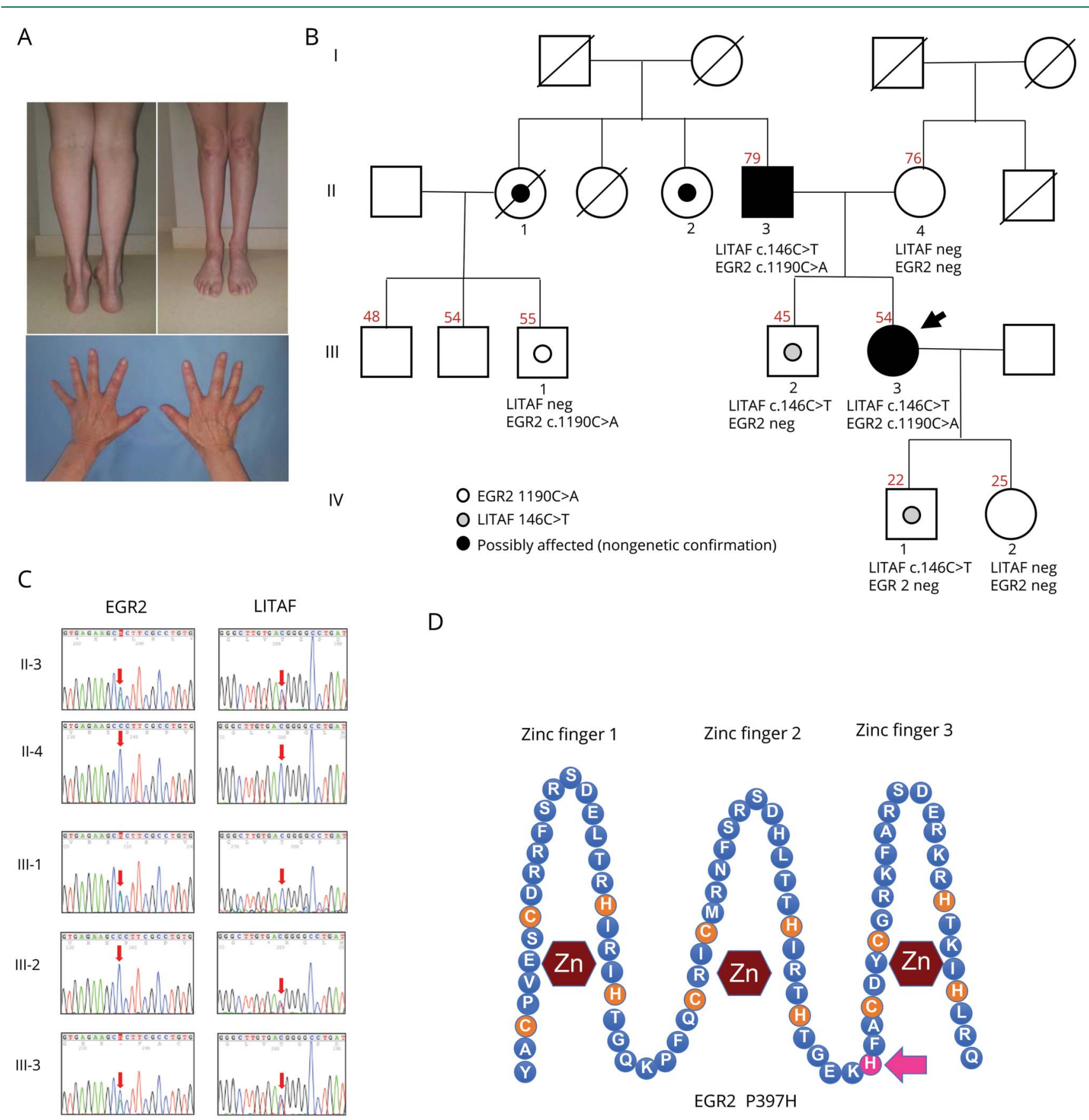

Zinc finger 1

Zinc finger 2

Zinc finger 3

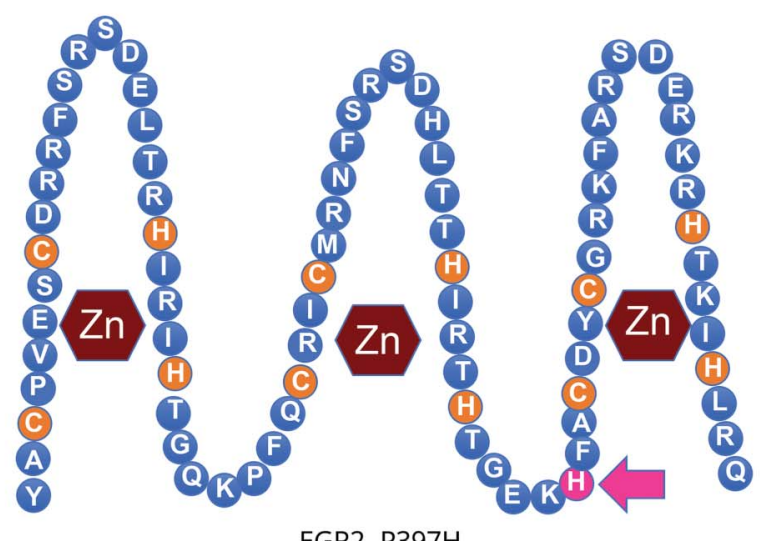

EGR2 P397H
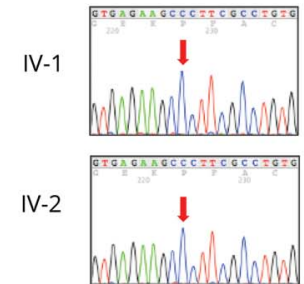
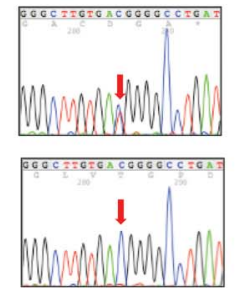

P51774 | EGR2_RAT P08152|EGR2 MOUSE P11161|EGR2_HUMAN P26632|EGR1 DANRE Q08427 | EGR2 XENLA Q98T82|Q98T82_CHICK A4 IIY8 | A4 IIY8 XENTR
THIRTHTGEKPFACDYCGRKFARSDERKRHTKIHLRQKERK THIRTHTGEKPFACDYCGRKFARSDERKRHTKIHLRQKERK THIRTHTGEKPFACDYCGRKFARSDERKRHTKIHLRQKERK THIRTHTGEKPFACEICGRKFARSDERKRHTKIHMRQKDKK THIRTHTGEKPFACDYCGRKFARSDERKRHTKIHLRQKERK THIRTHTGEKPFACDFCGRKFARSDERKRHTKIHLRQKERK THIRTHTGEKPFACDYCGRKFARSDERKRHTKIHLRQKERK

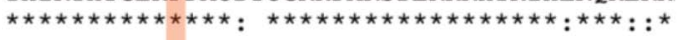

(A) Images obtained from the proband (III.3) showing atrophy of the posterior leg muscle compartment that generates lower limbs in inverted champagne bottle. In the upper limbs, hand muscles and thenar eminence were also atrophied. (B) Family pedigree. Ages at the moment of exploration are indicated in red. The arrow indicates the proband. LITAF neg, EGR neg: tested for mutations with negative results. (C) Chromatograms of members of the family. A red arrow indicates the position of the potentially mutated nucleotide. (D) Cartoon showing the localization of the newly identified mutation in the loop connecting zinc fingers 2 and 3 of the EGR2 transcription factor (arrow in the upper image). The alignment of the equivalent region of EGR2 from 7 different species shows that this is a highly evolutionary conserved sequence (lower image). LITAF = lipopolysaccharide-induced TNF-a factor. 
Committee of the General Hospital of Alicante approved the study. All adult participants provided informed consent for clinical and genetic analysis.

\section{Statistical analysis}

Values are presented as mean \pm standard error among comparison groups, and statistical significance of group differences was estimated with the Student $t$ test. A critical $p$ value of less than 0.05 was considered significant. Analysis was performed using GraphPad software (version 6.0).

\section{Data availability}

The data that support the study findings are available from the corresponding authors on reasonable request.

\section{Results}

\section{Clinical studies of the proband}

The proband (III.3 in figure 1B) was a 54-year-old woman with an intermediate hereditary motor and sensory neuropathy, with chronic axonal damage diagnosed at age 47 years in a neurophysiologic study. Initial symptoms began in the early childhood with progressive muscular atrophy and gait instability. At the most recent examination in April 2018 (figure 1A), the distal upper and lower limbs showed moderate-severe atrophy with associated weakness, arched feet, and Achilles tendon shortening. Reflexes were decreased or abolished. All sensory modalities were diminished. The CMT neuropathy score (CMTNS) ${ }^{13}$ value was 20. In the neurophysiologic study, motor nerve conduction velocities were slightly decreased in the median nerve, and no compound action potentials could be detected in the lower limbs (peroneal and tibial nerves) (table 1). Sensory nerve conduction velocities were decreased in the median and sural nerves, and action potentials were undetectable in the peroneal nerve.

\section{Genetic study of the proband}

The proband (III.3 in figure 1B) underwent a detailed genetic study to identify the mutated gene that was putatively responsible for the disease. After ruling out PMP22 duplication, 34 candidate genes (table e-1, links.lww.com/NXG/A244) associated with CMT disease were selected for nextgeneration sequencing. No previously described pathogenic mutations were found in any of these genes. However, the patient shows a previously described variant of the LITAF gene (c.146C>T; p.Thr49Met), considered to be a polymorphism, as it has been found in both symptomatic and nonsymptomatic individuals ${ }^{7,10}$ (figure $1, \mathrm{~B}$ and $\mathrm{C}$ ). This variant is predicted to produce the change of threonine 49 by a methionine in the LITAF polypeptide (LITAF T49M). Of interest, the proband also demonstrated a previously undescribed missense mutation in EGR2 (c.1190C>A; p.Pro397His) (figure $1, B$ and $C$ ). This nucleotide substitution is predicted to produce a change of the proline 397 by a histidine (EGR2 P397H) within the loop sequence that connects zinc finger numbers 2 and 3 (figure 1D). The presence of both mutations in heterozygosis was confirmed by amplifying the proband's genomic DNA by PCR and sequencing with the Sanger method (III.3 in figure 1C).

\section{EGR2 (c.1190C>A; p.Pro397His) associates with CMT disease only in a LITAF (c.146C $>\mathrm{T}$; p.Thr49Met) genetic background}

To determine whether the EGR2 P397H mutation is associated with the disease, we performed a cosegregation study of this mutation with CMT symptoms in other members of the family. The proband's father, aged 79 years (II.3 in figure 1B), referred instability, falls, and distal paresthesia for about 20 years. Our neurologic examination showed hand interosseous and distal lower limb atrophy with almost normal muscle strength. Reflexes were decreased in the legs, and arched feet were also observed. Electrodiagnostic study demonstrated a chronic intermediate sensory and motor polyneuropathy, with predominance in the lower limbs (table 1). The CMTNS value was 9, indicating a mild disability.

EGR2 (c.1190C>A; p.Pro397His) was found in heterozygosis in the father, suggesting an association of the mutation with the symptoms. However, he also expresses the LITAF T49M variant, precluding the possibility of establishing an unequivocal association between the EGR P397H mutation and the CMT symptoms. The proband's mother (II.4 in figure 1, B and C) does not have these mutations in EGR2 and LITAF genes.

The proband's brother (III.2 in figure 1B) was aged 45 years. His neurologic examination showed slight lower distal limb atrophy, flat feet, and Achilles tendon retraction. Nerve conduction velocity studies revealed a selective motor axonal neuropathy in both tibial nerves without data of complete polyneuropathy (table 1). Genetic studies showed the LITAF T49M variant (in heterozygosis) but no mutation in the EGR2 gene (figure 1C). The son (IV.1 in figure 1, B and C) showed the LITAF T49M in heterozygosis but was asymptomatic and neurologically normal. The daughter (IV.2 in figure 1, B and C) was also asymptomatic and did not show any of these mutations. Next, we explored other members of the family. Two of the proband's aunts were likely affected, but one of them (II.1 in figure 1B) died before the study, and the other (II.2 in figure 1B) did not want to participate in the study. The 55-year-old proband's cousin (III.1 in figure 1, B and C) was also examined. He had never complained of symptoms, and the neurologic examination was normal. Electrophysiology revealed an exclusively sensitive demyelinating polyneuropathy, probably due to the diabetes mellitus type 1 background (table 1 ). Of interest, the genetic study revealed that he had the EGR2 P397H variant in heterozygosis but no mutation in LITAF. Thus far, our data showed that only those members of the family with the EGR2 P397H and LITAF T49M develop CMT symptoms.

\section{EGR2 P397H has a decreased transcriptional activity}

Mutations in EGR2 cause distinct forms of demyelinating peripheral neuropathies including CMT1 type D and Dejerine-Sottas neuropathy, among others. ${ }^{6}$ Many of these 
Table 1 Electrophysiologic findings of the proband (III-3), father (II-3), brother (III-2), and cousin (III-1)

\begin{tabular}{|c|c|c|c|c|}
\hline & Proband III-3 & II-3 & III-3 & III-1 \\
\hline \multicolumn{5}{|l|}{ Motor nerve conduction } \\
\hline \multicolumn{5}{|l|}{ Median nerve } \\
\hline Distal latency $(\mathrm{ms})(<4.2)$ & 4.40 & 4.75 & 2.85 & 3.9 \\
\hline CMAP $(m V)(>3.5)$ & 4.9 & 3.5 & 5.6 & 6.5 \\
\hline $\operatorname{MCV}(m / s)(>48)$ & 45.4 & 44.5 & 54.4 & 49.3 \\
\hline \multicolumn{5}{|l|}{ Ulnar nerve } \\
\hline Distal latency $(\mathrm{ms})(<3.4)$ & 3.05 & 2.1 & 2.65 & 3.3 \\
\hline CMAP $(m V)(>2.8)$ & 5.0 & 6.6 & 6.4 & 6.3 \\
\hline $\operatorname{MCV}(m / s)(>50)$ & 47.8 & 59.4 & Normal & Normal \\
\hline \multicolumn{5}{|l|}{ Peroneal nerve } \\
\hline Distal latency $(\mathrm{ms})(<5.5)$ & NR & NR & 4.1 & Normal \\
\hline CMAP $(m V)(>2.5)$ & NR & NR & 5.8 & Normal \\
\hline $\operatorname{MCV}(\mathrm{m} / \mathrm{s})(>40)$ & NR & 14.8 & 57.1 & Normal \\
\hline \multicolumn{5}{|l|}{ Tibial nerve } \\
\hline Distal latency $(\mathrm{ms})(<6.0)$ & NR & 8.05 & 3.65 & 5.0 \\
\hline CMAP $(m V)(>2.9)$ & NR & 0.1 & 2.0 & 4.1 \\
\hline $\operatorname{MCV}(\mathrm{m} / \mathrm{s})(>41)$ & NR & NR & 30.9 & 41.2 \\
\hline
\end{tabular}

\section{Sensory nerve conduction}

\begin{tabular}{|c|c|c|c|c|}
\hline \multicolumn{5}{|l|}{ Median nerve } \\
\hline SNAP $(\mu \mathrm{V})(>19)$ & 5.8 & 3.7 & 39.6 & Normal \\
\hline $\operatorname{SCV}(\mathrm{m} / \mathrm{s})(>47)$ & 43.0 & 29.8 & 51.4 & Decreased \\
\hline \multicolumn{5}{|l|}{ Ulnar nerve } \\
\hline SNAP $(\mu \mathrm{V})(>18)$ & 4.2 & 5.8 & 24.8 & Normal \\
\hline $\operatorname{SCV}(m / s)(>44)$ & 36.6 & 42.6 & 48.8 & Normal \\
\hline \multicolumn{5}{|l|}{ Peroneal nerve } \\
\hline $\operatorname{SNAP}(\mu \mathrm{V})(>3.5)$ & NR & 1.2 & 4.6 & 3.9 \\
\hline $\operatorname{SCV}(\mathrm{m} / \mathrm{s})(>40)$ & NR & 26.7 & 52.9 & 36.5 \\
\hline \multicolumn{5}{|l|}{ Sural nerve } \\
\hline $\operatorname{SNAP}(\mu \mathrm{V})(>4.9)$ & 4.8 & 0.43 & 6.5 & 5.4 \\
\hline $\operatorname{SCV}(\mathrm{m} / \mathrm{s})(>41.3)$ & 33.8 & 25.6 & 47.9 & 41.7 \\
\hline \multicolumn{5}{|c|}{$\begin{array}{l}\text { Abbreviations: CMAP = compound muscle action potential; HMSN = hereditary sensory and motor neuropathy; MCV = motor conduction velocity; NR = } \\
\text { nonrecordable; SCV = sensory conduction velocity; SNAP = sensory nerve action potential. } \\
\text { Abnormal values are written in bold. Precise data for the peroneal and median nerve for patient III-1 were not available. The nerve conduction velocities and } \\
\text { amplitudes were predominantly more decreased in the lower than in the upper limbs, with peroneal and sural nerve severe injury in the proband and her father. } \\
\text { Peroneal nerve motor and sensory conduction velocities were NR for the proband. Tibial nerve motor conduction velocity was NR for the proband (III-3) and her } \\
\text { father (II-3). Proband III-3 had motor tibial nerve damaged with a prevailing axonal pattern. The proband's cousin (patient III-1) showed a selective sensory } \\
\text { peroneal and right median nerve conduction velocity decline without HMSN complete criteria. }\end{array}$} \\
\hline
\end{tabular}

mutations map in 1 of the 3 zinc finger domains of the transcription factor. The consequence of these mutations is generally the loss of DNA binding capacity. Although not strictly located within the zinc fingers, proline 397 is an evolutionary conserved residue located within a loop that connects zinc finger 2 with zinc finger 3 (figure 1D). Importantly, mutations in the equivalent proline (P368) in nerve growth factor induced gene A (a related zinc finger protein) block its transcriptional activity. ${ }^{14}$ To learn how $\mathrm{P} 397 \mathrm{H}$ change affects EGR2 function, we introduced this mutation in the construct pcDNA3.1 hEGR2. Seeking to 
determine whether the mutation alters the stability of EGR2 polypeptide, HEK293 cells were transfected with wild-type and mutant constructs. As is shown in figure $2 \mathrm{~A}$, both proteins were expressed at similar levels, illustrating that the mutation does not affect protein stability. Moreover, the EGR2 P397H mutant localized into the nucleus probing that the mutation does not change the subcellular localization of this transcription factor (figure $2 \mathrm{~B}$ ). Then, we evaluated the transcriptional activity of EGR2 P397H using an enhancer cloned upstream of the human P2 PMP22 promoter sequence and the pGL4 luciferase reporter. ${ }^{15}$ As is shown in figure 2C, EGR2 wild type induced luciferase activity by more than 28 -fold over the basal activity (pcDNA3.1 empty vector). By contrast, the EGR2 P397H mutant increased the activity by only 13 -fold.

To better approach the in vivo situation in the nerves of our patients, we decided to explore the transcriptional activity of the EGR2 P397H mutant in transfected primary cultures of Schwann cells. As is shown in figure 2D, EGR P397H is normally expressed and localized and has decreased transcriptional activity, including in Schwann cells as well. To determine whether the loss of transcriptional activity is caused by decreased capacity of the EGR2 P397H to bind DNA, HEK293 cells were transfected with the wild-type and mutant EGR2 and nucleus isolated (see Methods). Nuclear extracts were allowed to bind a doublestranded biotinylated oligonucleotide with a tandem-repeated EGR2-binding consensus sequence (see Methods, e-Methods, links.lww.com/NXG/A245). DNA-protein complexes were captured in the assay microwell and quantified colorimetrically with an anti-EGR2-specific antibody (see Methods, e-Methods, links.lww.com/NXG/A245). As is shown in figure 3A, both wildtype and mutant EGR2 showed similar binding capability DNA. To further confirm this result, we performed ChIP assays on the PMP22 enhancer in transfected HEK293 cells (see Methods). As is highlighted in figure 3B, ChIP assay confirmed that the $\mathrm{P} 397 \mathrm{H}$ mutation does not change the capacity of EGR2 to bind DNA.

\section{LITAF T49M protein has decreased stability}

Initial studies postulated that LITAF itself might act as a transcription factor. ${ }^{8,16}$ Indeed, recent studies have shown that LITAF has a cysteine-rich region that coordinates zinc. ${ }^{17,18} \mathrm{We}$ explored whether LITAF could positively regulate the transcription of myelin genes. To this aim, HEK293 cells were cotransected with phPMP22enh-Luciferase and the plasmids encoding for the human LITAF sequence. As shown in figure 3C, LITAF was not able to induce the transcription of PMP22, neither increase the transcriptional activity of EGR2, ruling out a direct upregulation of EGR2 transcriptional activity by this protein. We also ruled out a direct physical interaction between LITAF and EGR2 proteins by coimmunoprecipitation studies (figure e-1, links.lww.com/NXG/A243). LITAF has been shown to participate in the recruitment of endosomal sorting complex required for transport components to endosomal membranes regulating ErbB receptor trafficking and consequently NRG1 signaling in Schwann cells. ${ }^{9}$ Because NRG1 signaling is pivotal for EGR2 induction and Schwann cell differentiation, ${ }^{19}$ we hypothesized that LITAF T49M may interfere with EGR2 expression in the Schwann cells of the double heterozygotes. One possibility was that this mutation had a loss of function effect by decreasing protein stability. Of interest, during the coimmunoprecipitation studies performed in HEK cells (figure e-1, links.lww.com/NXG/ A243), we noticed that the LITAF T49M GFP fusion protein was consistently much less expressed compared with the LITAF-GFP wild type. To learn whether the T49H mutation affects LITAF protein stability also in Schwann cells, we transfected cultured Schwann cells with LITAF-GFP and LITAF T49M GFP constructs. As is shown in figure 3D, the number of cells expressing detectable levels of LITAF protein was notably lower when the mutant construct was transfected, suggesting decreased protein stability. To further substantiate this hypothesis, RT4D6 Schwannoma cells were transfected with the LITAF T49M GFP and the LITAF-GFP constructs. After 48 hours, cells were lyzed, and protein extracts were immunoblotted with a polyclonal anti-LITAF antibody. Anti-glyceraldehyde-3phosphate dehydrogenase immunoblot was used as a loading control. As is shown in figure 3E, the LITAF T49M GFP protein was less abundant than LITAF-GFP also in these cells. A similar result was obtained when the GFP tag was removed from the constructs. Together, our results show that the T49M mutation produces a decrease in the stability of the LITAF polypeptide that could interfere with NRG1erbB signaling in Schwann cells.

\section{Discussion}

CMT disease is a hereditary peripheral neuropathy caused by distinct mutations in more than 40 different genes. One of these genes is EGR2, a pivotal master gene in the establishment of the myelin gene expression program by Schwann cells. ${ }^{4,6,12}$ Indeed, more than 30 missense mutations causing peripheral neuropathy have been described in this transcription factor (hihg.med.miami.edu/code/http/cmt/public_html/index.html\#/). Most of these mutations are located in the zinc finger region, a domain essential for the transcriptional activity of EGR2. Using next-generation sequencing, we discovered a novel mutation of this domain in EGR2 (EGR2 P397H) in a family with CMT clinical symptoms. Using promoter activity assays, we found that this mutant has a decreased transcriptional activity compared with the wild type. Surprisingly, DNA binding and ChIP assays suggest that this mutant transcription factor binds efficiently to myelin gene promoters. Of interest, a similar mutation in the zinc finger transcription factor nerve growth factor induced gene A (P369) that blocks transcriptional activity does not interfere with DNA binding. ${ }^{14}$ Together, these data suggest that this proline residue is involved in the recruitment of other proteins such as coactivators, but not in the binding of EGR2 to DNA. Experiments to address this point are currently being performed in our laboratory.

We found that this family also expressed a mutation in LITAF (LITAF T49M). Although other missense mutations in this 
A. HEK 293

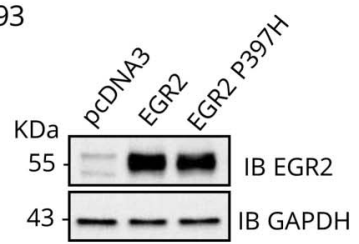

C. HEK 293

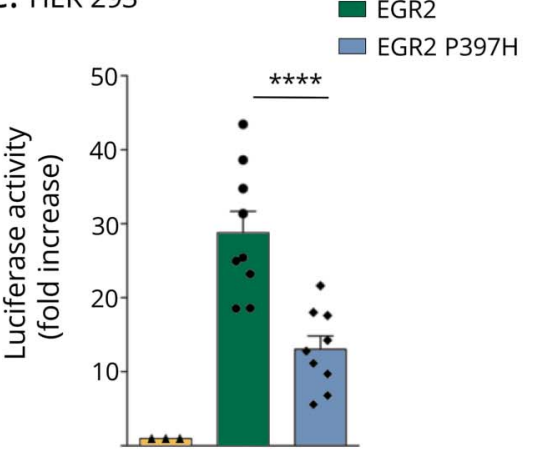

D. Schwann cells

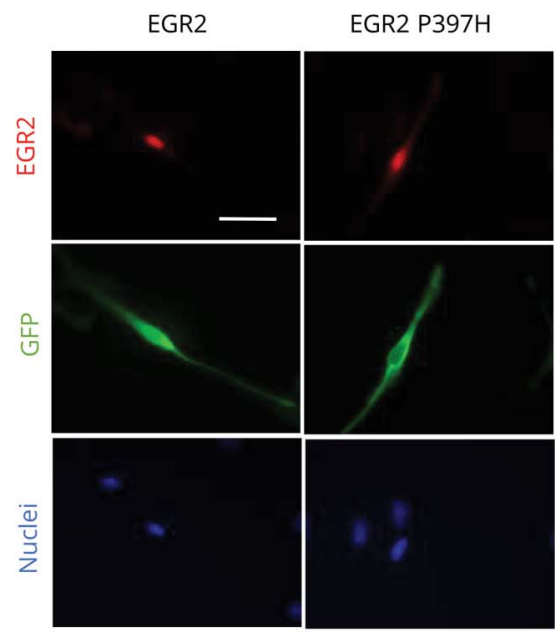

B

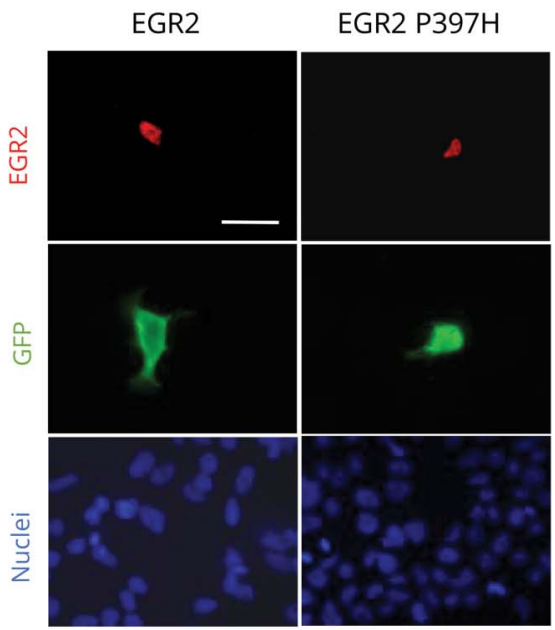

E. Schwann cells

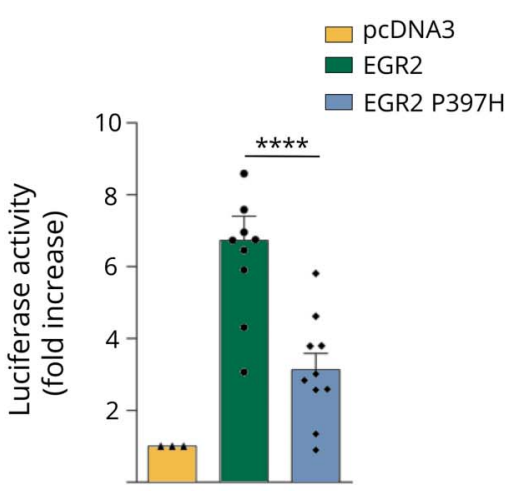

(A) Western blot of HEK293 cells transfected with an empty vector (pcDNA3.1), pcDNA3.1 hEGR2 (EGR2), and pcDNA3.1 hEGR2 P397H (EGR2 P397H). GAPDH was used as a loading control. No change in the stability of the mutant protein is observed. (B) Immunofluorescence with anti-EGR2 antibody of HEK293 cotransfected cells with the different EGR2 constructs and GFP demonstrate that both wild-type and mutant proteins localize properly in the nucleus (labeled with Hoechst staining). Anti-GFP immunofluorescence highlights those cells that have been transfected. Bars $25 \mu \mathrm{m}$. (C) P397H decreases the transcriptional activity of EGR2. HEK293 cells were transfected with phPMP22enh-Luciferase and an empty vector (pcDNA3), EGR2 or EGR2 P397H and luciferase activity determined. Results were normalized against the activity of the pRSV40-LacZ vector. Data are given as mean \pm standard error (SE)

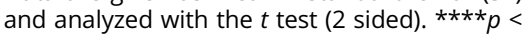
0.0001 . (D) Immunofluorescence with antiEGR2 antibody of Schwann cells cotransfected with the different EGR2 constructs and GFP showing both wild-type and mutant proteins localized in the nucleus. Anti-GFP immunofluorescence highlights transfected cells. Bars $25 \mu \mathrm{m}$. (E) As in HEK293 cells, the transcriptional activity of EGR2 P397H also decreases in Schwann cells. Data are given as mean $\pm \mathrm{SE}$ and analyzed with the $t$ test (2 sided). $\star \star \star \star x p<$ 0.0001 . GAPDH $=$ glyceraldehyde-3-phosphate dehydrogenase; GFP = green fluorescent protein; LITAF = lipopolysaccharide-induced TNF-a factor. gene cause CMT type $1 \mathrm{C}$ disease, this particular variant has been considered a polymorphism, as it was found in asymptomatic members of other pedigrees. ${ }^{10}$ Indeed, our analysis confirms that at least 2 members of the family who present this mutation (III.2 and IV.1) have no CMT compatible clinical symptoms and are normal in the neurologic exploration.

Surprisingly, and despite of the decreased transcriptional activity of the EGR2 P397H, only those members of the family who have both mutations at the same time developed CMT symptoms (members II.3 and III.3). Indeed, the cousin of the proband (member III.1), who has only the EGR2 P397H mutation, and is of similar age, does not show CMT symptoms. Although this provides strong evidence that both mutations are necessary to develop the clinical symptoms, we cannot completely rule out that an incomplete penetrance of the EGR P397H mutation could explain our findings. Genetic and clinical characterization of other lineages will help to clarify this point.

Initially, we reasoned that a physical interaction between LITAF and EGR2 proteins could explain the genetic interaction. However, we could not detect any binding of LITAF to EGR2, neither a positive effect of LITAF on the transcriptional activity of EGR2.

It has been shown that the loss of function of LITAF produces deregulation in the NRG1-erbB signaling in Schwann 

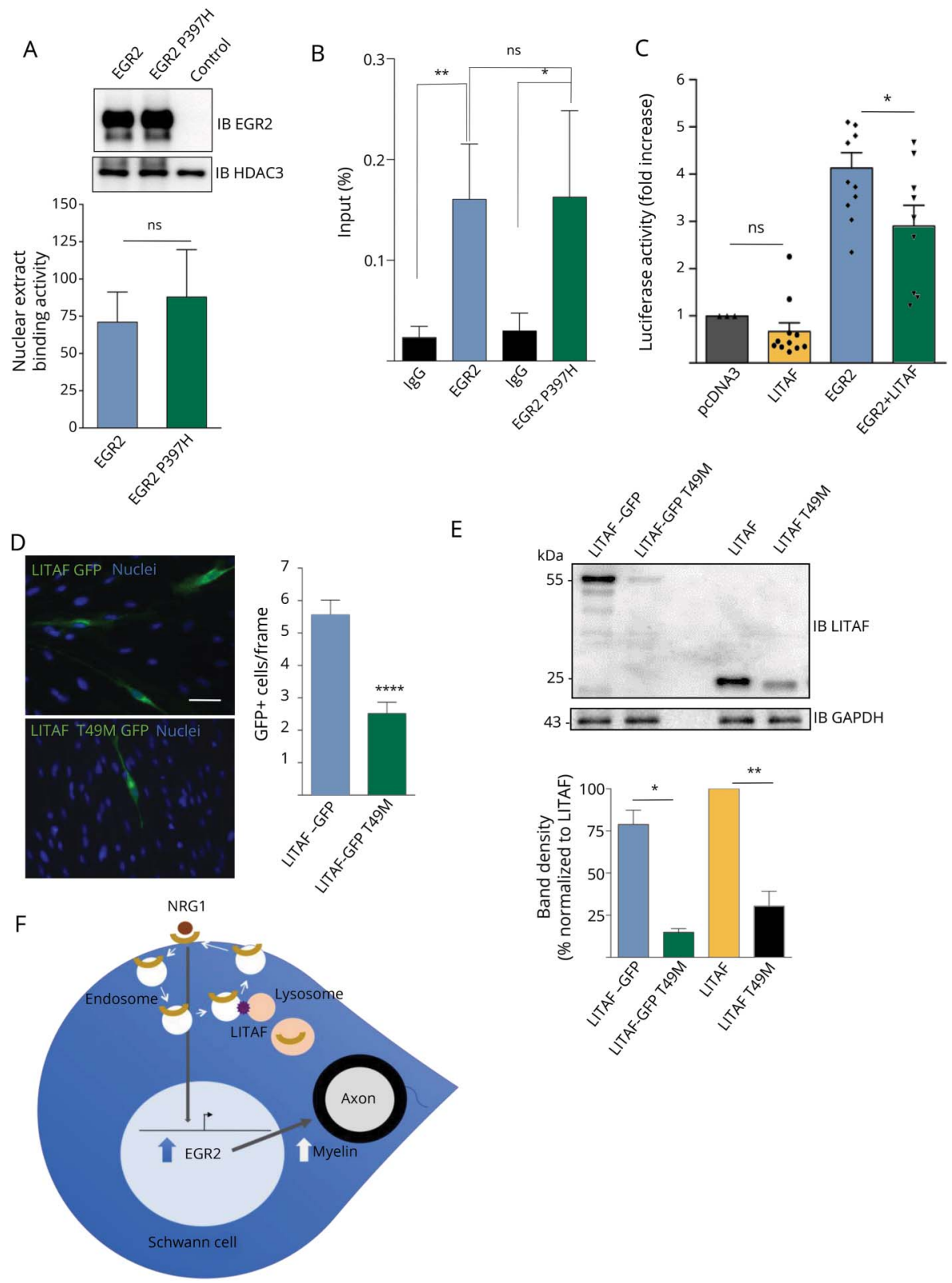

(A) EGR2 P397H binds normally to DNA in vitro. HEK293 cells were transfected with the constructs pcDNA3.1-EGR2 and pcDNA3.1-EGR2 P397H and nuclear extracts obtained. Biotinylated oligonucleotides with the EGR2-binding sequence in tandem (3 repeats) were incubated with nuclear extracts. Anti-EGR2 polyclonal antibody was used to quantify colorimetrically the binding of EGR2 to the oligonucleotide (see Methods). Nuclear extracts of nontransfected and GFP-transfected cells were used as controls. Data are given as mean \pm standard error (SE) and analyzed with the $t$ test ( 2 sided). $(n=7)$. (B) EGR2 P397H binds normally to DNA in vivo. HEK293 cells were transfected with pcDNA3.1-EGR2 and pcDNA3.1-EGR2 P397H and cross-linked with PFA. Chromatin was purified and immunoprecipitated with anti-EGR2 antibody or a nonspecific IgG (chromatin immunoprecipitation grade). qPCR was performed with specific primers for the enhancer region of PMP22. As shown, the recovery of the PMP22 enhancer region in the immunoprecipitate was similar in both cases. No relevant recovery was obtained with the nonspecific IgG. Data are given as mean \pm SE and analyzed with the paired $t$ test $\left(2\right.$ sided). ${ }^{*} p<0.05 ; * * p<0.01(\mathrm{n}=10)$. (C) LITAF has no PMP22 transcriptional activity and does not increase EGR2 transcriptional activity. HEK293 cells were transfected with phPMP22enh-Luciferase and an empty vector (pCDNA3), LITAF, EGR2, or LITAF + EGR2 and luciferase activity determined. Results were normalized against the activity of the pRSV40-LacZ vector. Data are given as mean \pm SE and analyzed with the $t$ test ( 2 sided). A slight tendency to decrease the basal activity of the reporter by the LITAF construct was observed. ${ }^{*} p<0.05$. (D) LITAF T49M has decreased stability. Cultured Schwann cells were transfected with LITAF-GFP and LITAF T49M GFP constructs. The number of cells expressing detectable levels of LITAF protein was notably lower with the mutant construct. Bar 25 um. Quantification of immunofluorescence showing the percentage of GFP positive per frame $(n=30)$. Data are given as mean \pm SE and analyzed with the $t$ test $(2$ sided). $(E) I m m u n o b l o t ~ a n a l y s i s$ supports a decreased stability for the LITAF T49M polypeptide. RT4D6 cells were transfected with the LITAF T49M GFP and the LITAF-GFP constructs, lysed, and protein extracts immunoblotted with a polyclonal anti-LITAF antibody. Anti-GAPDH immunoblot was used as a loading control. A similar result was obtained when the GFP tag was removed. The densitometry of 3 different experiments is shown. Data are given as mean \pm SE and analyzed with the $t$ test $\left(2\right.$ sided). ${ }^{*} p<0.05 ;{ }^{*} p<0.01$. (F) Working model: a reduction in the function of the LITAF T49M protein decreases the expression of an already transcriptionally deficient EGR2 P397H hampering myelin development and nerve function. GAPDH = glyceraldehyde-3phosphate dehydrogenase; GFP = green fluorescent protein; LITAF = lipopolysaccharide-induced TNF-a factor; PFA = paraformaldehyde; qPCR: quantitative polymerase chain reaction. 
cells. ${ }^{9}$ Of interest, we observed that the steady-state levels of the LITAF T49M mutant protein (in both heterologous systems and in Schwann cells) are consistently much lower than the wild-type form, suggesting a loss of function mechanism. Because adequate NRG1-erbB signaling is pivotal for EGR2 expression and myelin development, it is conceivable that although a partial decrease in the transcriptional activity of EGR2 P397H or a partial loss of LITAF function does not individually interfere with myelin development, in the compound heterozygotes, the deregulated NRG1-erbB signaling (consequence of a partial loss of LITAF function) will deficiently induce an already transcriptional defective EGR2, interfering with myelin development and peripheral nervous system function.

\section{Acknowledgment}

The authors thank the participating relatives of the patient for their cooperation throughout this study. They thank Dr. Cruz Morenilla-Palao (Instituto de Neurociencias UMH-CSIC, Spain) for advice in ChIP and other molecular biology experiments. They thank Dr. Philip Woodman and Dr. Lydia Wunderley (University of Manchester, UK) for providing pGFP-hLITAF and pGFP-hLITAF T49M plasmids, John Svaren (University of Wisconsin) for pPMP22enh-Luciferase, and Dies Meijer (University of Edinburgh, UK) for RT4D6 Schwannoma cells. They also thank Pedro Morenilla-Ayala for technical assistance.

\section{Study funding}

This work has been funded by grants BFU2016-75864R (MINECO Spanish Ministry for Economy and Competitiveness), PROMETEO 2018/114 (Conselleria Educació Generalitat Valenciana), and UGP-15-211 (FISABIO) to H. Cabedo.

\section{Disclosure}

Disclosures available: Neurology.org/NG.

\section{Publication history}

Received by Neurology: Genetics May 8, 2019. Accepted in final form December 30, 2019.

Appendix Author

\begin{tabular}{|c|c|c|}
\hline Name & Location & Contribution \\
\hline $\begin{array}{l}\text { Maria } \\
\text { Empar } \\
\text { Blanco- } \\
\text { Cantó, MD }\end{array}$ & $\begin{array}{l}\text { ISABIAL (FISABIO), Hospital } \\
\text { General Universitario de } \\
\text { Alicante, Spain }\end{array}$ & $\begin{array}{l}\text { Major role in the } \\
\text { acquisition of data; } \\
\text { designed and } \\
\text { conceptualized the study; } \\
\text { analyzed and interpreted } \\
\text { the data; and drafted the } \\
\text { manuscript for } \\
\text { intellectual content }\end{array}$ \\
\hline $\begin{array}{l}\text { Nikiben } \\
\text { Patel, MSc }\end{array}$ & $\begin{array}{l}\text { ISABIAL (FISABIO), Hospital } \\
\text { General Universitario de } \\
\text { Alicante and Instituto de } \\
\text { Neurociencias de Alicante } \\
\text { UMH-CSIC, Spain }\end{array}$ & $\begin{array}{l}\text { Major role in the } \\
\text { acquisition of data; } \\
\text { analyzed and interpreted } \\
\text { the data; and drafted the } \\
\text { manuscript for } \\
\text { intellectual content }\end{array}$ \\
\hline
\end{tabular}

Appendix (continued)

\begin{tabular}{|c|c|c|}
\hline Name & Location & Contribution \\
\hline $\begin{array}{l}\text { Sergio } \\
\text { Velasco- } \\
\text { Aviles, MSc }\end{array}$ & $\begin{array}{l}\text { ISABIAL (FISABIO), Hospital } \\
\text { General Universitario de } \\
\text { Alicante and Instituto de } \\
\text { Neurociencias de } \\
\text { Alicante UMH-CSIC, } \\
\text { Spain }\end{array}$ & $\begin{array}{l}\text { Major role in the } \\
\text { acquisition of data and } \\
\text { analyzed and interpreted } \\
\text { the data }\end{array}$ \\
\hline $\begin{array}{l}\text { Angeles } \\
\text { Casillas- } \\
\text { Bajo, BSc }\end{array}$ & $\begin{array}{l}\text { ISABIAL (FISABIO), Hospital } \\
\text { General Universitario de } \\
\text { Alicante and Instituto de } \\
\text { Neurociencias de Alicante } \\
\text { UMH-CSIC, Spain }\end{array}$ & $\begin{array}{l}\text { Major role in the } \\
\text { acquisition of data }\end{array}$ \\
\hline $\begin{array}{l}\text { Juan Salas- } \\
\text { Felipe, MD }\end{array}$ & $\begin{array}{l}\text { Hospital Marina Salud, } \\
\text { Denia, Spain }\end{array}$ & $\begin{array}{l}\text { Major role in the } \\
\text { acquisition of data }\end{array}$ \\
\hline $\begin{array}{l}\text { Alexandre } \\
\text { García- } \\
\text { Escrivá, MD }\end{array}$ & $\begin{array}{l}\text { Hospital IMED Levante, } \\
\text { Benidorm, Spain }\end{array}$ & $\begin{array}{l}\text { Major role in the } \\
\text { acquisition of data }\end{array}$ \\
\hline $\begin{array}{l}\text { Carmen } \\
\text { Díaz-Marín, } \\
\text { MD, PhD }\end{array}$ & $\begin{array}{l}\text { ISABIAL (FISABIO), Hospital } \\
\text { General Universitario de } \\
\text { Alicante, Spain }\end{array}$ & $\begin{array}{l}\text { Designed and } \\
\text { conceptualized the study; } \\
\text { analyzed and interpreted } \\
\text { the data; and } \\
\text { drafted the manuscript } \\
\text { for intellectual } \\
\text { content }\end{array}$ \\
\hline $\begin{array}{l}\text { Hugo } \\
\text { Cabedo, } \\
\text { MD, PhD }\end{array}$ & $\begin{array}{l}\text { ISABIAL (FISABIO), Hospital } \\
\text { General Universitario de } \\
\text { Alicante and Instituto de } \\
\text { Neurociencias de Alicante } \\
\text { UMH-CSIC, Spain }\end{array}$ & $\begin{array}{l}\text { Designed and } \\
\text { conceptualized the study; } \\
\text { analyzed and } \\
\text { interpreted the data; } \\
\text { and drafted the } \\
\text { manuscript for } \\
\text { intellectual content }\end{array}$ \\
\hline
\end{tabular}

\section{References}

1. Rossor AM, Polke JM, Houlden H, Reilly MM. Clinical implications of genetic advances in Charcot-Marie-Tooth disease. Nat Rev Neurol 2013;9:562-571.

2. Berciano J, Sevilla T, Casasnovas C, et al. Guidelines for molecular diagnosis of Charcot-Marie-Tooth disease [in Spanish]. Neurologia 2012;27:169-178.

3. Gonzaga-Jauregui C, Harel T, Gambin T, et al. Exome sequence analysis suggests that genetic burden contributes to phenotypic variability and complex neuropathy. Cell Rep 2015;12:1169-1183.

4. Nagarajan R, Svaren J, Le N, Araki T, Watson M, Milbrandt J. EGR2 mutations in inherited neuropathies dominant-negatively inhibit myelin gene expression. Neuron 2001;30:355-368.

5. Srinivasan R, Sun G, Keles S, et al. Genome-wide analysis of EGR2/SOX10 binding in myelinating peripheral nerve. Nucleic Acids Res 2012;40:6449-6460.

6. Warner LE, Svaren J, Milbrandt J, Lupski JR. Functional consequences of mutations in the early growth response 2 gene (EGR2) correlate with severity of human myelinopathies. Hum Mol Genet 1999;8:1245-1251.

7. Saifi GM, Szigeti K, Wiszniewski W, et al. SIMPLE mutations in Charcot-MarieTooth disease and the potential role of its protein product in protein degradation. Hum Mutat 2005;25:372-383.

8. Lee SM, Olzmann JA, Chin LS, Li L. Mutations associated with Charcot-MarieTooth disease cause SIMPLE protein mislocalization and degradation by the proteasome and aggresome-autophagy pathways. J Cell Sci 2011;124: 3319-3331.

9. Lee SM, Chin LS, Li L. Charcot-Marie-Tooth disease-linked protein SIMPLE functions with the ESCRT machinery in endosomal trafficking. J Cell Biol 2012; 199:799-816.

10. Beauvais K, Furby A, Latour P. Clinical, electrophysiological and molecular genetic studies in a family with X-linked dominant Charcot-Marie-Tooth neuropathy presenting a novel mutation in GJB1 promoter and a rare polymorphism in LITAF/ SIMPLE. Neuromuscul Disord 2006;16:14-18.

11. Brockes JP, Fields KL, Raff MC. Studies on cultured rat Schwann cells. I. Establishment of purified populations from cultures of peripheral nerve. Brain Res 1979;165: $105-118$.

12. Jang SW, LeBlanc SE, Roopra A, Wrabetz L, Svaren J. In vivo detection of Egr2 binding to target genes during peripheral nerve myelination. J Neurochem 2006;98: $1678-1687$. 
13. Shy ME, Blake J, Krajewski K, et al. Reliability and validity of the CMT neuropathy score as a measure of disability. Neurology 2005;64:1209-1214.

14. Wilson TE, Day ML, Pexton T, Padgett KA, Johnston M, Milbrandt J. In vivo mutational analysis of the NGFI-A zinc fingers. J Biol Chem 1992;267: 3718-3724.

15. Jones EA, Lopez-Anido C, Srinivasan R, et al. Regulation of the PMP22 gene through an intronic enhancer. J Neurosci 2011;31:4242-4250.

16. Myokai F, Takashiba S, Lebo R, Amar S. A novel lipopolysaccharide-induced transcription factor regulating tumor necrosis factor alpha gene expression: molecular cloning, sequencing, characterization, and chromosomal assignment. Proc Natl Acad Sci USA 1999;96:4518-4523.

17. Ho AK, Wagstaff JL, Manna PT, et al. The topology, structure and PE interaction of LITAF underpin a Charcot-Marie-Tooth disease type 1C. BMC Biol 2016;14:109.

18. Qin W, Wunderley L, Barrett AL, High S, Woodman PG. The Charcot Marie Tooth disease protein LITAF is a zinc-binding monotopic membrane protein. Biochem J 2016;473:3965-3978.

19. Arthur-Farraj P, Wanek K, Hantke J, et al. Mouse schwann cells need both NRG1 and cyclic AMP to myelinate. Glia 2011;59:720-733. 


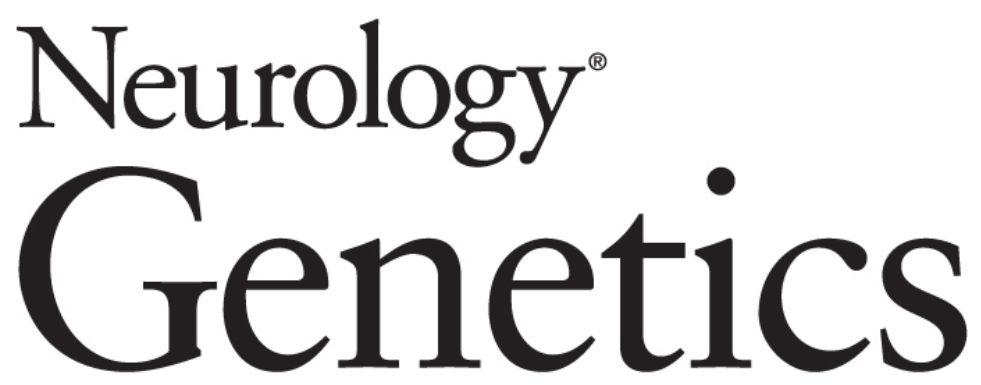

Novel EGR2 variant that associates with Charcot-Marie-Tooth disease when combined with lipopolysaccharide-induced TNF- $\alpha$ factor T49M polymorphism

Maria Empar Blanco-Cantó, Nikiben Patel, Sergio Velasco-Aviles, et al. Neurol Genet 2020;6;

DOI 10.1212/NXG.0000000000000407

This information is current as of March 3, 2020

Neurol Genet is an official journal of the American Academy of Neurology. Published since April 2015, it is an open-access, online-only, continuous publication journal. Copyright Copyright ( 2020 The Author(s).

Published by Wolters Kluwer Health, Inc. on behalf of the American Academy of Neurology.. All rights reserved. Online ISSN: 2376-7839.

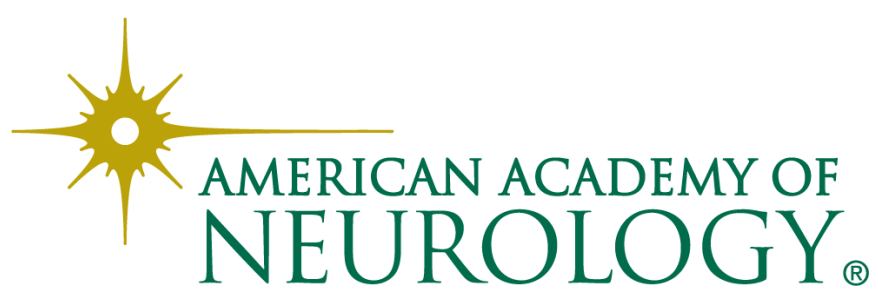




\section{Updated Information \& Services}

References

Subspecialty Collections

Permissions \& Licensing

\section{Reprints}

including high resolution figures, can be found at: http://ng.neurology.org/content/6/2/e407.full.html

This article cites 19 articles, 6 of which you can access for free at: http://ng.neurology.org/content/6/2/e407.full.html\#\#ref-list-1

This article, along with others on similar topics, appears in the following collection(s):

All Demyelinating disease (CNS)

http://ng.neurology.org//cgi/collection/all_demyelinating_disease_cns All Genetics

http://ng.neurology.org//cgi/collection/all_genetics

All Movement Disorders

http://ng.neurology.org//cgi/collection/all_movement_disorders All Neuromuscular Disease

http://ng.neurology.org//cgi/collection/all_neuromuscular_disease Peripheral neuropathy

http://ng.neurology.org//cgi/collection/peripheral_neuropathy

Information about reproducing this article in parts (figures,tables) or in its entirety can be found online at:

http://ng.neurology.org/misc/about.xhtml\#permissions

Information about ordering reprints can be found online:

http://ng.neurology.org/misc/addir.xhtml\#reprintsus

Neurol Genet is an official journal of the American Academy of Neurology. Published since April 2015, it is an open-access, online-only, continuous publication journal. Copyright Copyright $\odot 2020$ The Author(s). Published by Wolters Kluwer Health, Inc. on behalf of the American Academy of Neurology.. All rights reserved. Online ISSN: 2376-7839.

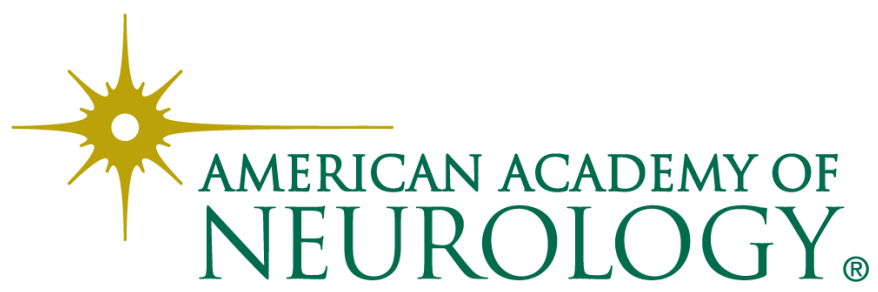

